\title{
Ověření konceptu akademického optimismu na českých školách druhého stupně povinného vzdělávání ${ }^{1}$
}

\author{
Jana Straková, Jaroslava Simonová, David Greger
}

Univerzita Karlova, Pedagogická fakulta, Ústav výzkumu a rozvoje vzdělávání

\begin{abstract}
Redakci zasláno 12. 2. 2017 / upravená verze obdržena 1. 6. 2017 /
\end{abstract}
k uveřejnění přijato 1. 6. 2017

\begin{abstract}
Abstrakt: Výzkumy efektivity školního vzdělávání poukázaly na význam přesvědčení a postojů učitelů pro vyučování a učení žáků. Přesvědčení a postoje zásadně ovlivňují chování učitelů a jejich př́istup $\mathrm{k}$ žákům a jejich rodičům. Změna přesvědčení je nezbytným předpokladem pro změnu práce učitelů a vzdělávání obecně. Přesvědčení učitelů jsou v pedagogickém výzkumu konceptualizována mnoha různými způsoby, tato studie si klade za cíl lokalizovat nástroje na měření konceptu akademického optimismu. Akademický optimismus je konceptualizován ve dvou podobách - jako kolektivní charakteristika pedagogického sboru a jako individuální charakteristika každého jednotlivého učitele - a kombinuje tři důležité aspekty učitelova profesního kréda: vnímání vlastních učitelských dovedností a možností pedagogické práce, důvěru k žákům a jejich rodičům a důraz na studijní výsledky. Studie lokalizuje oba koncepty a klade si za cíl vybrat vhodnější z nich pro české prostředí. Zároveň zkoumá souvislost mezi akademickým optimismem a výsledkem žáků. $V$ analýzách jsou využita data z šetření na 39 základních školách získaná od 325 učitelů a 1316 žáků 9. ročníků v rámci šetření projektu Kalibro v roce 2016. Dvouúrovňová konfirmační analýza ukázala použitelnost obou modelů, přičemž vhodnějším pro české prostředí se jeví model individuální. Dvouúrovňové strukturní modelování neprokázalo na tomto limitovaném výběru žáků souvislost mezi akademickým optimismem a výsledky žáků v matematice, tuto souvislost bude nutno ověřit na reprezentativním výběru s využitím testů více zohledňujících současnou kurikulární normu.
\end{abstract}

Klíčová slova: přesvědčení učitelů, akademický optimismus, základní škola, rodinné zázemí, výsledky vzdělávání

Výzkumy efektivity školního vzdělávání poukázaly na význam přesvědčení a postojů učitelů pro vyučování a učení žáků. Přesvědčení a postoje zásadně

1 Text je výstupem řešení projektu GA ČR: Vztahy mezi dovednostmi, vzděláváním a výsledky na trhu práce: longitudinální studie (číslo P402/12/G130). Autoři velice děkují PhDr. Ing. Petrovi Soukupovi, Ph.D. z Fakulty sociálních věd Univerzity Karlovy za pomoc při práci s víceúrovňovými modely v software MPlus. 
ovlivňují chování učitelů a jejich přístup k žákům a jejich rodičům. Změna přesvědčení je nezbytným předpokladem pro změnu práce učitelů a vzdělávání obecně (např. Woolfolk Hoy, Hoy, \& Kurz, 2008; Reynolds et al., 2015).

Přesvědčení učitelů jsou v pedagogickém výzkumu konceptualizována mnoha různými způsoby. Pro tuto studii jsme zvolili koncept akademického optimismu, který kombinuje tři důležité aspekty učitelova profesního kréda: vnímání vlastních učitelských dovedností a možností pedagogické práce (self-efficacy ${ }^{2}$ ), důvěru k žákům a jejich rodičům (trust) a důraz na studijní výsledky (academic emphasis).

Akademický optimismus má velký potenciál vysvětlit postoje učitelů ke znevýhodněným žákům. Toto téma je velmi relevantní pro současnou situaci v českém vzdělávacím systému, kdy je České republice opakovaně vytýkáno, že není schopna poskytnout kvalitní vzdělávání romským žákům (např. Amnesty International, 2015). Věříme, že jednou z důležitých příčin tohoto problému jsou přesvědčení učitelů týkající se motivace romských žáků, jejich učebních možností a důvěryhodnosti.

Cílem analýz popisovaných $\mathrm{v}$ této stati bylo ověřit funkčnost konceptu akademického optimismu v české základní škole a prozkoumat vztah mezi akademickým optimismem a výsledky vzdělávání.

\section{Koncept akademického optimismu}

Akademický optimismus zdůrazňuje potenciál školy překonat socioekonomické faktory, které negativně ovlivňují výsledky žáků. Namísto zdůrazňování bezmoci školy tváří $\mathrm{v}$ tvář znevýhodňujícímu rodinnému prostředí se zaměřuje na její možnosti (Hoy, Tarter, \& Woolfolk Hoy, 2006). Bylo opakovaně prokázáno, že akademický optimismus má pozitivní dopad na výsledky žáků bez ohledu na socioekonomický status, předchozí studijní výsledky žáka i na rozmanité demografické charakteristiky. Tato souvislost byla doložena v různých vzdělávacích systémech, například v americkém Texasu (Smith \& Hoy, 2007), ve Virginii (Kirby \& DiPaola, 2011) a v Alabamě (Bevel

\footnotetext{
Pro termín self-efficacy neexistuje ustálený český překlad. Můžeme se setkat například s výrazy vnímaná vlastní účinnost, vnímaná osobní účinnost, vnímaná osobní zdatnost, vnímaná sebe-výkonnost, obecná vlastní efektivita, sebeuplatnění, přičemž žádný z použitých výrazů původní anglický termín dobře nevystihuje. $Z$ toho důvodu někteří autoři zůstávají u původního anglického termínu (Smetáčková, Vozková, 2016). My jsme se rozhodli v tomto textu používat překlad vnímaná účinnost, i když jsme si dobře vědomi jeho omezení.
} 
\& Mitchell, 2012), v kanadském Ontariu (Mascall et al., 2008), na Tchajwanu (Chang, 2011; Wu, 2013; Wu, Hoy, \& Tarter, 2013), v Iránu (Moghari et al., 2011), v Jihoafrické republice (Ngidi, 2012), v Turecku (Eren, 2014; Kösterelioğlu, 2017; Sezgin \& Erdogan, 2015), v Pákistánu (Anwar \& Anis-ulHaque, 2014) a ve vlámské části Belgie (Boonen et al., 2014). Modifikovaný ukazatel akademického optimismu byl použit ve výzkumu TIMSS 2011 pod názvem důraz školy na studijní úspěch (school emphasis on academic success - SEAS - viz Dvořák, 2015). Ve výzkumu TIMSS byla pozitivní vazba mezi tímto ukazatelem a výsledky testu prokázána ve většině zúčastněných zemí (Martin et al., 2013). Pozitivní dopad důrazu školy na studijní úspěch byl prokázán také ve studiích národních (např. Nilsen \& Gustafsson, 2014).

Koncept akademického optimismu má původ $\mathrm{v}$ pozitivní psychologii (Pajares, 2001) a v Bandurově sociálně-kognitivní teorii a teorii vnímané účinnosti (Bandura, 1986, 1997, cit. podle Hoy, 2012). Na obecné úrovni je vnímaná účinnost přesvědčení o kapacitě osoby organizovat a vykonávat činnosti požadované pro realizaci výkonu na dané úrovni (Bandura, 1997). Právě Bandurovo zjištění, že korelace mezi kolektivní vnímanou účinností a výsledky žákủ byla silnější než korelace mezi socioekonomickým zázemím (SES) a výsledky žáků (Bandura, 1993), inspirovalo Hoye a jeho kolegy k prozkoumání toho, zda kolektivní vnímaná účinnost může přispívat k lepším výsledkům žáků nezávisle na jejich SES.

Jedná se o latentní konstrukt, sestávající ze tří úzce souvisejících konceptů učitelem vnímané vlastní účinnosti, učitelovy důvěry $\mathrm{k}$ žákům a jejich rodičům a učitelova důrazu na vytváření pozitivního a stimulujícího studijního prostředí (např. Hoy et al., 2006; McGuigan \& Hoy, 2006; Woolfolk Hoy et al., 2008). Koncept vzešel z dlouholetého úsilí Wayna K. Hoye, jeho studentů a spolupracovníků (Hoy, 2012) a v ucelené podobně byl poprvé publikován v roce 2006 Waynem K. Hoyem, jeho manželkou Anitou Woolfolk Hoyovou a C. Johnem Tarterem (Hoy et al., 2006). Konstrukt čerpá ze tří teoretických zdrojů. Koncept kolektivní vnímané účinnosti vychází z Bandurovy sociálně-kognitivní teorie, důvěra z Colemanovy analýzy sociální interakce (Coleman et al., 1966, cit. podle Hoy, 2012) a akademický důraz z organizačního zdraví škol, které teoreticky vychází z Parsonse, Balese a Shilse (1953, cit. podle Hoy, 2012). Autoři byli také inspirováni Seligmanovými pracemi o konceptu naučeného optimismu (Seligman, 1991, 1998; cit. podle Hoy, 2012), do kterého $\mathrm{z}$ jejich pohledu dobře zapadal jak koncept vnímané účinnosti, tak koncept důvěry. Akademický důraz pak zaměřil kolektivní optimismus školy na oblast akademických výsledků (odtud termín akademický optimismus). 
Jeho autoři tvrdí, že vedle tradičně vnímaných předpokladů školního úspěchu, kterými jsou talent a motivace, je důležitým prediktorem úspěchu i optimismus, jehož význam je srovnatelný s prvními dvěma faktory. Dle Seligmana (1998) je ho navíc možné rozvíjet a je možné se mu naučit.

Akademický optimismus je důležitý faktor ovlivňující dobré výsledky žáků i na úrovni organizace. Kolektivní vnímaná účinnost vybavuje učitele sebevědomím, že mohou efektivně pracovat se žáky i v případě obtíží. Motivuje učitele konat tak, aby si stanovovali náročné cíle a vytrvali, dokud nebudou úspěšní. Důvěra rodičů pak povzbuzuje učitele k zavádění inovací bez obav, že jim bude vyčítáno, když změní svůj přístup, a podněcuje spolupráci rodičů a učitelů. Tím se v chování aktivuje důraz na akademické výsledky, protože žáci i rodiče mají důvěru v učitele.

Po ověření funkčnosti konceptu kolektivního akademického optimismu se manželé Hoyovi se svými spolupracovníky zaměřili na individuální akademický optimismus - zajímalo je, zda je konstrukt funkční i na individuální úrovni. Vycházeli z předpokladu, že všechny tři základní koncepty - vnímaná účinnost, důvěra a akademický důraz - mají paralelní význam i na úrovni jednotlivých učitelů (Woolfolk Hoy et al., 2008). Akademický optimismus na individuální úrovni definovali jako učitelovo přesvědčení, že může mít vliv na výsledky žáků tím, že zdůrazňuje význam dobrých výsledků a učení, důvěřuje žákům a rodičům, že budou v procesu učení spolupracovat, a že věři ve vlastní kapacitu překonat těžkosti a reagovat na problémy vytrvalostí a houževnatostí. Při zdokonalování konstruktu (Beard, Hoy, \& Hoy, 2010) se ukázalo, že i když je učitelova důvěra v rodiče a žáky jedním faktorem, tak je důvěrou v rodiče sycena více než důvěrou v žáky. To bylo ovšem pochopitelné vzhledem ke skutečnosti, že konstrukt byl primárně ověřován na učitelích prvního stupně. $V$ další studii, která se zaměřila na úroveň střední školy, pak byl tento faktor již více sycen důvěrou v žáky (Fahy, Wu, \& Hoy, 2010). Vlastní účinnost vnímaná učitelem je považována za kognitivní charakteristiku a je definována jako učitelovo „posouzení své schopnosti docílit žádoucích výsledků z hlediska zaujetí žákủ a jejich učení, a to i v případě žáků, kteří nejsou motivováni nebo mají studijní obtíže" (Woolfolk Hoy et al., 2008). Zahrnuje nejen vědomí vlastních schopností, které ukazují, že učitel zvládl učitelskou profesi, ale rovněž víru ve školní vzdělávání coby důležitou instituci, která může zásadně ovlivnit životy žáků a jejich budoucnost. Věří-li učitelé tomu, že mohou ovlivnit učení žáků, kladou na ně vyšší nároky, vynakládají vyšší úsilí na dosažení žádoucích výsledků a vytrvávají i v případě obtíží. 
Druhá složka je považována za složku postojovou a ukazuje, že efektivní učitelé musí být schopni navazovat se svými žáky a jejich rodiči vztahy založené na vzájemné důvěře. Takové vztahy jsou založeny na shovívavosti, spolehlivosti, kompetentnosti, čestnosti a otevřenosti. Obecně platí, že učitelé musí důvěřovat tomu, že jejich žáci jsou otevření učení, mají schopnost porozumět vyučovaným konceptům a jsou čestní. Musí věřit ve spolupráci s rodiči žáků. Analogicky jako $\mathrm{v}$ př́ípadě vnímané účinnosti učitelé mají větší očekávání od žáků, kterým důvěřují a $v$ jejichž případě věří, že se mohou spolehnout na podporu jejich rodičů (Woolfolk Hoy et al., 2008).

Důraz na studijní výsledky se vztahuje k přesvědčením učitelů týkajícím se akademických výsledků jejich žákủ a jejich zaměření na akademické cíle. Zahrnuje stanovování vysokých a zároveň dosažitelných cílů a trvání na svědomité důkladné práci (Woolfolk Hoy et al., 2008).

Všechny výše popsané složky akademického optimismu jsou ve vzájemném vztahu a společně tvoří vědomí akademického optimismu u pedagogů. Učitelova důvěra v rodiče a žáky podporuje učitelovo vnímání vlastní účinnosti a vnímání vlastní účinnosti posiluje důvěru. Pokud učitel důvěřuje rodičům, může nastavit vysoké akademické nároky, nebot' se může spolehnout, že jeho snaha nebude rodiči podkopávána. Vysoké nároky, které přinášejí výsledky, na druhé straně posilují učitelovu důvěru. V neposlední řadě učitelovo přesvědčení, že může pozitivně ovlivnit výsledky žáků, podporuje akademické výsledky a důraz na akademické výsledky naopak podporuje učitelovo vnímání vlastní účinnosti (Hoy et al., 2006).

Kombinování všech tří výše popsaných složek do jednoho společného konceptu má důležité důsledky pro vzdělávací politiku: každý program nebo intervence, které si kladou za cíl zlepšit jednu složku akademického optimismu, musí zároveň podporovat zbylé dvě složky. To např́́klad znamená, že není možné zavádět opatření na zlepšení akademických výsledkủ, která podkopávají důvěru mezi žáky, učiteli a rodiči. To jsou typicky všechna opatření založená na konkurenci a represi.

\section{Výzkumné otázky}

Mezinárodní výzkumy výsledků vzdělávání ukázaly, že čeští učitelé mají ve srovnání se svými zahraničními kolegy nízké vědomí vlastní účinnosti a vykazují také nízkou důvěru ke svým žákům a jejich rodičům (Martin et al., 2013; OECD, 2014). Cílem analýzy představené v této stati je zjistit, zda je 
možné pro popis postojů českých učitelů použít koncept akademického optimismu a zda má akademický optimismus dopad na výsledky žákủ. Pozitivní odpověd' na obě otázky by znamenala, že je třeba u budoucích a praktikujících učitelů kultivovat nejen jejich obsahové a procedurální znalosti (týkající se toho, co a jak vyučovat), ale také jejich profesní přesvědčení.

Akademický optimismus byl původně zjištován na úrovni školy jako kolektivní charakteristika učitelského sboru dané školy, kdy se učitelé vyjadřovali „o učitelích v jejich škole“ (např. Hoy et al., 2006; McGuigan \& Hoy, 2006). Když jsme se dotazovali českých učitelů na to, jaké mají názory a postoje učitelé v jejich škole nebo jak si učitelé v jejich škole počínají při výuce, učitelé nám opakovaně odpovídali, že o svých kolezích nemohou spolehlivě vypovídat, že nám mohou říci pouze to, jak si počínají nebo co si myslí oni sami. Zdá se, že v českých školách podle jejich názoru v některých oblastech neexistují sdílené postoje a prrístupy, každý učitel si počíná zcela autonomně tak, jak to považuje za správné a efektivní. Výzkumy českých učitelů také ukázaly, že výpovědi učitelů o nich samých se odlišovaly od výpovědí o jejich škole jako celku. Učitelé se zpravidla viděli v „lepším světle“, než v jakém viděli své kolegy: jako ty, kteří jsou progresívnější než jejich kolegové, lépe rozumějí požadavkům kurikulární reformy, lépe si dovedou poradit s nároky, které na ně klade, a podobně (Straková et al., 2013). Proto jsme využili skutečnosti, že byl akademický optimismus konceptualizován také na individuální úrovni jako charakteristika individuálních učitelů, kdy učitelé vypovídají o sobě samých, nikoli o pedagogickém sboru jako celku (Fahy et al., 2010). Postupovali jsme tak, že jsme administrovali dotazníky zjišttující kolektivní i individuální akademický optimismus s tím, že v dalších studiích budeme využívat ten konstrukt, který se v českém kontextu lépe osvědčí. Hledali jsme tedy odpovědi na následující výzkumné otázky:

1) Je možné v kontextu české školy využít kolektivní koncept akademického optimismu?

2) Je možnév kontextučeskéškolyvyužítindividuální koncept akademického optimismu?

3) Je některý z obou konceptů vhodnější pro použití ve výzkumech českých učitelů?

Cílem analýz prezentovaných $\mathrm{v}$ této stati bylo tedy lokalizovat nástroje pro měření kolektivního a individuálního akademického optimismu do českého prostředí a ověřit jejich funkčnost $\mathrm{v}$ prostředí české školy $\mathrm{s}$ tím, že 
v následných výzkumech bude pak zkoumána souvislost mezi akademickým optimismem a výsledky vzdělávání. Nicméně i v této analýze jsme pilotně ověřovali souvislost akademického optimismu s výsledky žáků. Průřezová povaha získaných dat nám striktně vzato neumožňuje zjištovat kauzální souvislosti, pouze vztahy mezi proměnnými. Naše poslední výzkumná otázka tedy zněla takto:

4) Existuje souvislost mezi akademickým optimismem a výsledky žáků v matematickém testu i po zohlednění socioekonomického složení žákư?

Při konstrukci modelu jsme vycházeli z práce Boonena a kol. (2014), kteří ukázali, že na školách ve vlámské části Belgie akademický optimismus pedagogů statisticky významně ovlivňuje výsledky žáků bez ohledu na to, jaké je složení žáků, kteří školu navštěvují.

\section{Výzkumný soubor}

V lednu 2016 byly dotazníky obsahující dotazníkové baterie zjišt’ující kolektivní i individuální koncept akademického optimismu administrovány 429 učitelům na 102 základních školách. Dotazování proběhlo v rámci šetření Kalibro, při kterém byli testováni žáci 9. ročníků na stejných školách jako $\mathrm{v}$ roce $1996 \mathrm{z}$ matematiky a českého a anglického jazyka, přičemž cílem šetření bylo zjistit, do jaké míry došlo ke změnám ve znalostech žáků těchto škol. Výběr tedy není možné považovat za náhodný, jedná se o školy, které dlouhodobě využívají projekt Kalibro k hodnocení vědomostí a dovedností jejich žáků. Vzhledem k záměru studie, ověřit koncept akademického optimismu v českém prostředí, jsme považovali tento výběr škol za dostatečný.

Do naší analýzy byly zahrnuty výpovědi 325 učitelů ze 39 základních škol, ve kterých jsme získali dotazníky minimálně od 5 učitelů vyučujících na 2. stupni. Na těchto školách bylo testováno celkem 1316 žáků.

\section{Výzkumné metody}

Pro zjištování kolektivního konceptu akademického optimismu byla využita baterie autorů Hoy a kol. (2006), která byla využita rovněž ke studiu akademického optimismu ve vlámské části Belgie (Boonen et al., 2014). Tato baterie zahrnovala osm otázek na vnímání vlastní účinnosti (self efficacy - SE), devět otázek týkajících se důvěry (trust - TR) a pět otázek zjištujujících důraz na studijní výsledky (academic emphasis - AE). 
Ke zjištování individuálního konceptu byla využita baterie autorů Fahy a kol. (2010). Tato baterie zahrnovala tři otázky na každou z výše uvedených tří složek. Všechna tvrzení, se kterými učitelé vyjadřovali míru souhlasu na šestibodové škále, byla přeložena do češtiny autory studie. Při překladu byla věnována velká péče tomu, aby položky dávaly v českém prostředí smysl a zároveň byl zachován jejich původní význam. Srozumitelnost položek byla opakovaně testována v individuálních rozhovorech s učiteli.

Funkčnost obou konceptů byla ověřována prostřednictvím dvouúrovňové konfirmační analýzy. Dvouúrovňový model byl použit z toho důvodu, že studovaný jev by se měl primárně projevovat na úrovni školy, i když jeho nositeli jsou jednotliví učitelé. Správnost použití dvouúrovňového modelu potvrdily hodnoty koeficientů vnitrotřídní korelace jednotlivých tvrzení, které vykazovaly uvnitř škol v př́ípadě obou konceptů určitou míru podobnosti (podrobněji viz oddíl věnovaný výsledkům).

Vztah mezi výsledkem v matematickém testu a akademickým optimismem byl zjištován prostřednictvím víceúrovňového strukturního modelování. Do modelu vstupovaly následující proměnné:

- výsledek matematického testu Usp (procentuální úspěšnost);

- pohlaví (0 - dívka, 1 - chlapec);

- nejvyšší dosažené vzdělání HIED (nejvyšší dosažené vzdělání rodičů na škále 1 - základní, 2 - střední bez maturity, 3 - střední s maturitou, 4 - vysokoškolské).

Matematický test Kalibro byl identický s testem zadávaným v roce 1996. Obsahoval devět úloh, na jejichž vyřešení měli žáci jednu vyučovací hodinu. Úlohy byly zaměřeny na výpočet objemů těles, výpočty se zlomky, vlastnosti trojúhelníků, Pythagorovu větu, přímou úměru, algebraické výrazy, rovnice, sítě těles a grafickou prezentaci dat. Ve třech úlohách měli žáci za úkol samostatně spočítat výsledek, v pěti úlohách měli z pět až osm nabízených možností odpovědí zvolit všechny správné odpovědi (přičemž správná nemusela být ani jedna), $v$ jedné úloze měli za úkol vybrat z šesti nabízených možností jedinou správnou odpověd'. Úlohy byly koncipovány jako úsudkové, přičemž správná odpověd' vyžadovala opravdu důkladné porozumění ověřovanému učivu. ${ }^{3}$ Psychometrické charakteristiky testových položek ani testu jako celku nejsou k dispozici.

Forma výběru více správných možností je pro žáky velmi nezvyklá a může být do jisté míry matoucí. 
Jsme si vědomi toho, že nejvyšší dosažené vzdělání je pouze hrubým ukazatelem socioekonomického statusu. V žákovských výzkumech (např. výzkum OECD PISA) bývá zpravidla kombinováno ještě s počtem knih v domácnosti, majetky $\mathrm{v}$ rodině a povoláním, př́padně zaměstnaneckým statusem otce a matky. Projekt Kalibro tradičně používá pouze nejvyšší dosažené vzdělání rodičů, pravděpodobně z důvodu snahy o co nejnižší zatížení respondentů. Autoři této studie dodávali do výzkumu Kalibro pouze dotazníky pro učitele a do žákovských dotazníků nijak nezasahovali, proto jsou v analýzách odkázáni pouze na tuto proměnnou. Na základě analýz uskutečněných na jiných datových souborech však autoři usoudili, že nejvyšší dosažené vzdělání pro účely daných analýz dostatečně aproximuje socioekonomický status. ${ }^{4}$

Na úrovni školy bylo nejvyšší dosažené vzdělání agregováno a charakterizovalo složení žáků dané školy. Na úrovni školy byl do modelu zahrnut rovněž akademický optimismus, přičemž latentní proměnné byly konstruovány pomocí průměrných hodnot jednotlivých položek získaných od učitelů jednotlivých škol.

Deskriptivní charakteristiky proměnných vstupujících do modelu jsou uvedeny v prŕloze. Všechny výpočty byly provedeny v softwaru M-Plus.

Podíl chybějících hodnot v případě učitelských proměnných nepřesáhl 1,5 \%, u žákovských proměnných činil $1 \%$ v případě pohlaví a $5 \%$ v případě vzdělání rodičů. Protože podíl chybějících hodnot byl relativně nízký, nebyly použity žádné metody pro jejich kompenzaci.

Kvalita modelů byla posuzována podle následujících ukazatelů:

RMSEA - Root mean square error of approximation udává, jak dobře model odpovídá populační kovarianční matici. Hu a Bentler (1998) považují za maximální pro vyhovující modely hodnotu RMSEA 0,06.

TLI - Tucker-Lewis index hodnotí model na základě porovnání $\chi 2$ modelu a $\chi 2$ nulového modelu.

\footnotetext{
Např. v datovém souboru z výzkumu CLoSE (Czech Longitudinal Study in Education), který obsahoval data od reprezentativního výběru 4798 žáků 9. ročníků školního vzdělávání, byla hodnota Pearsonova korelačního koeficientu pro vzdělání matky s výsledkem testu v matematice 0,346 a pro vzdělání otce 0,332 , přičemž korelace počtu knih $v$ domácnosti s výsledkem činila 0,249 , povolání matky (1. kód klasifikace ISCO) 0,283 a povolání otce 0,270 . Faktorový skór všech uvedených proměnných, který zahrnul 50 \% rozptylu) vykazoval hodnotu korelace s výsledkem testu 0,438.
} 
CFI - Comparative fit index je analogický indexu TLI s tím, že bere v úvahu velikost výběru. Hu a Bentler (1998) považují za doklad dobré shody s daty v prrípadě ukazatelů TLI a CFI hodnoty vyšší než 0,9 .

SRMR - Standardized root mean square residual je druhá odmocnina z rozdílu mezi rezidui kovarianční matice a hypotetického kovariančního modelu. Za indikaci dobrého modelu je považována hodnota 0,5 a nižší (např. Byrne, 1998).

\section{$5 \quad$ Výsledky}

\subsection{Kolektivní koncept akademického optimismu}

Tabulka 1 uvádí průměry jednotlivých položek na škále 1-6, na které učitelé vyjadřovali souhlas s předloženými výroky $(1$ - zcela souhlasím, 6 - zcela nesouhlasím), směrodatné odchylky a koeficienty vnitrotřídní korelace. Tři výroky mají opačnou polaritu, pro účely zpracování byly tedy výpovědi překódovány.

Hodnoty koeficientu vnitrotřídní korelace ${ }^{5}$ poskytují představu o rozdílech mezi jednotlivými školami. Hodnota koeficientu se pro jednotlivé výroky pohybovala v rozmezí $0,03-0,19$, což potvrdilo, že je třeba vzít v úvahu hierarchickou povahu dat.

Hodnoty Cronbachova alfa potvrdily, že všechny škály, které jsou součástí konstruktu, vykazují dobrou vnitřní konsistenci: vnímaná účinnost měla hodnotu $\alpha=0,761$, důvěra $\alpha=0,877$, důraz na studijní výsledky $\alpha=0,764$. Celý konstrukt pak hodnotu $\alpha=0,889$. Všechny proměnné vykazovaly normální rozdělení a hodnota indikátoru KMO byla 0,631.

V dalším kroku jsme tedy provedli dvouúrovňovou konfirmační analýzu se všemi 22 položkami, prostřednictvím kterých jsme měřili kolektivní akademický optimismus se všemi jeho třemi latentními konstrukty (kolektivní vnímaná účinnost, důvěra pedagogického sboru a důraz školy na studijní výsledky) na úrovni učitele a školy. Tento model ovšem dobře neodpovídal datům (RMSEA = 0,07; CFI = 0,774; TLI = 0,758; SRMR na úrovni učitele 0,10; SRMR na úrovni školy 0,18$)$. Modifikační ukazatele poukázaly na osm špatně fungujících položek (SE1, SE4, SE6, TR1, TR2, TR8, TR9, AE5), které byly jedna po druhé odstraněny $\mathrm{z}$ modelu.

5 Vnitrotřídní korelace byly vypočítány jako podíly rozptylu dané proměnné na úrovni školy ku součtu rozptylu na úrovni školy a na úrovni učitele (viz např. Soukup, 2006). 
Tabulka 1

Položky kolektivního konceptu akademického optimismu

\begin{tabular}{|c|c|c|c|c|}
\hline \multicolumn{2}{|c|}{ Vnímaná účinnost } & \multirow{2}{*}{ průměr } & \multirow{2}{*}{$\frac{\mathrm{SD}}{1,16}$} & \multirow{2}{*}{$\frac{\text { ICC }}{0,03}$} \\
\hline SE1 & Žáci v naší škole prostě nejsou motivováni se učit (obráceno). & & & \\
\hline SE2 & $\begin{array}{l}\text { Pokud se žák nechce učit, učitelé v naší škole na jeho } \\
\text { vzdělávání rezignují (obráceno). }\end{array}$ & 4,82 & 1,23 & 0,11 \\
\hline SE3 & $\begin{array}{l}\text { Učitelé v naší škole jsou schopni si poradit i s těmi } \\
\text { nejproblémovějšími žáky. }\end{array}$ & 4,24 & 1,20 & 0,12 \\
\hline SE4 & $\begin{array}{l}\text { Učitelé v naší škole nemají dovednosti, které by jejich žákům } \\
\text { umožnily smysluplné učení. }\end{array}$ & 5,21 & 1,04 & 0,09 \\
\hline SE5 & Učitelé v naší škole věří, že každé dítě se může učit. & 4,76 & 1,24 & 0,06 \\
\hline SE6 & Žáci přicházejí do školy připraveni se učit. & 3,4 & 1,01 & 0,06 \\
\hline SE7 & Učitelé v naší škole nejsou schopni vypořádat se s nekázní. & 4,79 & 1,11 & 0,09 \\
\hline SE8 & $\begin{array}{l}\text { Učitelé v naší škole jsou přesvědčeni, že dovedou motivovat své } \\
\text { žáky (obráceno). }\end{array}$ & 4,55 & 0,91 & 0,04 \\
\hline \multicolumn{5}{|c|}{ Důvěra } \\
\hline TR1 & Žákům v naší škole záleží na spolužácích. & 4,27 & 0,95 & 0,19 \\
\hline TR2 & $\begin{array}{l}\text { Učitelé v naší škole se mohou spolehnout, že žáci udělají } \\
\text { zadanou práci. }\end{array}$ & 3,63 & 1,01 & 0,16 \\
\hline TR3 & Učitelé mohou věřit tomu, co jim rodiče říkají. & 3,47 & 1,09 & 0,11 \\
\hline TR4 & Učitelé v naší škole důvěřují rodičům. & 3,98 & 0,92 & 0,13 \\
\hline TR5 & Učitelé v naší škole si myslí, že většina rodičů se opravdu snaží. & 3,77 & 1,05 & 0,13 \\
\hline TR6 & Rodiče v naší škole spolehlivě plní své závazky. & 3,67 & 1,01 & 0,11 \\
\hline TR7 & Učitelé se mohou spolehnout na podporu rodičů. & 3,61 & 0,92 & 0,13 \\
\hline TR8 & Učitelé v naší škole věří, že žáci jsou schopni se učit. & 4,56 & 0,94 & 0,11 \\
\hline TR9 & Učitelé v naší škole důvěřují svým žákům. & 4,29 & 0,89 & 0,07 \\
\hline \multicolumn{5}{|c|}{ Důraz na studijní výsledky } \\
\hline AE1 & Žákům záleží na tom, aby měli dobré známky. & 4,02 & 1,01 & 0,19 \\
\hline AE2 & Žáci se v průběhu vyučovacích hodin aktivně zapojují do výuky. & 3,98 & 0,90 & 0,14 \\
\hline AE3 & Žáci se snaží si zlepšovat prospěch. & 3,95 & 0,85 & 0,08 \\
\hline AE4 & Žáci si váží spolužáků, kteří mají dobré známky. & 3,39 & 1,03 & 0,08 \\
\hline AE5 & Žáci nenosí domácí úkoly. & 3,28 & 1,17 & 0,10 \\
\hline
\end{tabular}

Výsledné redukované škály opět vykazovaly dobrou vnitřní konsistenci: pro vnímanou účinnost bylo $\alpha=0,694$, pro důvěru $\alpha=0,880$, pro důraz na studijní výsledky $\alpha=0,789$. Celý konstrukt vykazoval hodnotu $\alpha=0,830$. Odhad dvouúrovňového modelu se zbylými 14 položkami a tři latentními konstrukty již měl dobrý fit (RMSEA $=0,044 ; \mathrm{CFI}=0,947$; TLI $=0,940 ; \mathrm{SRMR}$ 
na úrovni učitele 0,05 ; SRMR na úrovni školy 0,13 ). Hodnoty SRMR ukazují, že fit na úrovni učitele je lepší než na úrovni školy. Na obou úrovních byly všechny faktorové zátěže statisticky významné $(\mathrm{p}<0,001)$. Faktorové zátěže na úrovni školy jsou silnější než faktorové zátěže na úrovni učitele, což naznačuje, že škály působí především na školní úrovni (tabulka 2). Residuální rozptyl položky AE3 a residuální rozptyl latentní proměnné důvěra (TR_SCH) na úrovni školy byly zafixovány na nulu (hodnoty obou proměnných byly nízké a záporné).

Tabulka 2

Dvouúrovňová konfirmační analýza, kolektivní akademický optimismus, Kalibro (faktorové zátěže na úrovni učitele a na úrovni školy)

\begin{tabular}{|c|c|c|c|c|c|c|}
\hline & \multicolumn{3}{|c|}{ úroveň učitele } & \multicolumn{3}{|c|}{ úroveň školy } \\
\hline proměnná & $\begin{array}{c}\text { vnímaná } \\
\text { účinnost } \\
\text { školy }\end{array}$ & $\begin{array}{l}\text { důvěra } \\
\text { k žákům } \\
\text { a rodičům }\end{array}$ & $\begin{array}{c}\text { důraz } \\
\text { na studijní } \\
\text { výsledky }\end{array}$ & $\begin{array}{c}\text { vnímaná } \\
\text { účinnost } \\
\text { školy }\end{array}$ & $\begin{array}{l}\text { důvěra } \\
\text { k žákům } \\
\text { a rodičům }\end{array}$ & $\begin{array}{c}\text { důraz } \\
\text { na studijní } \\
\text { výsledky }\end{array}$ \\
\hline SE2 & 0,462 & & & 0,576 & & \\
\hline SE3 & 0,614 & & & 0,733 & & \\
\hline SE5 & 0,641 & & & 0,994 & & \\
\hline SE7 & 0,455 & & & 0,684 & & \\
\hline SE8 & 0,501 & & & 0,977 & & \\
\hline TR3 & & 0,718 & & & 0,943 & \\
\hline TR4 & & 0,705 & & & 0,959 & \\
\hline TR5 & & 0,715 & & & 0,996 & \\
\hline TR6 & & 0,756 & & & 0,988 & \\
\hline TR7 & & 0,818 & & & 0,967 & \\
\hline AE1 & & & 0,688 & & & 0,796 \\
\hline AE2 & & & 0,671 & & & 0,811 \\
\hline AE3 & & & 0,859 & & & 0,999 \\
\hline AE4 & & & 0,565 & & & 0,879 \\
\hline & SE & TR & $\mathrm{AE}$ & SE_SCH & TR_SCH & AE_SCH \\
\hline $\mathrm{AO}$ & 0,616 & 0,609 & 0,587 & 0,922 & 1,000 & 0,916 \\
\hline
\end{tabular}

\subsection{Individuální koncept akademického optimismu}

Tabulka 3 uvádí položky konceptu individuálního akademického optimismu spolu s jejich průměry, směrodatnými odchylkami a koeficienty vnitrotřrídní korelace. $\mathrm{V}$ případě individuálního konceptu dosahovaly koeficienty 
vnitrotřídní korelace hodnot v rozmezí 0,06 až 0,11. Tedy i zde, přestože jsme se dotazovali na přesvědčení a př́stupy jednotlivých učitelů, se projevily rozdíly mezi jednotlivými školami a bylo vhodné volit dvouúrovňový model.

Použité škály i zde vykazovaly dobrou vnitřní konzistenci: vnímaná účinnost $\alpha=0,747$, důvěra $\alpha=0,815$, důraz na studijní výsledky $\alpha=0,794$. Celý konstrukt vykazoval hodnotu $\alpha=0,838$. Všechny proměnné měly normální rozdělení, hodnota indikátoru KMO byla výrazně vyšší než v prŕípadě kolektivního konstruktu a činila 0,912.

Tabulka 3

Položky individuálního konceptu akademického optimismu

\begin{tabular}{|c|c|c|c|c|}
\hline \multicolumn{2}{|c|}{ Vnímaná účinnost } & \multirow{2}{*}{$\begin{array}{c}\text { průměr } \\
3,96\end{array}$} & \multirow{2}{*}{$\frac{\mathrm{SD}}{0,93}$} & \multirow{2}{*}{$\begin{array}{l}\text { ICC } \\
0,06\end{array}$} \\
\hline SE1 & Daří se mi motivovat žáky, kteří nemají zájem o školní práci. & & & \\
\hline SE2 & Daří se mi přesvědčit žáky, že mohou mít dobré výsledky. & 4,32 & 0,86 & 0,10 \\
\hline SE3 & $\begin{array}{l}\text { Daří se mi dosahovat toho, aby žáci dodržovali pravidla } \\
\text { ve třídě. }\end{array}$ & 4,63 & 0,82 & 0,07 \\
\hline \multicolumn{5}{|c|}{ Důvěra } \\
\hline TR1 & Moji žáci jsou většinou slušní a poctiví. & 4,49 & 0,91 & 0,16 \\
\hline TR2 & Na rodiče svých žáků se mohu spolehnout. & 4,13 & 0,98 & 0,09 \\
\hline TR3 & Důvěřuji svým žákům. & 4,51 & 0,97 & 0,08 \\
\hline \multicolumn{5}{|c|}{ Důraz na studijní výsledky žáků } \\
\hline AE1 & Kladu důraz na to, aby se moji žáci dobře učili. & 4,95 & 0,90 & 0,10 \\
\hline AE2 & Předkládám svým žákům náročné učivo. & 3,99 & 1,08 & 0,11 \\
\hline AE3 & Svým žákům stanovuji vysoké ale dosažitelné cíle. & 4,32 & 1,05 & 0,08 \\
\hline
\end{tabular}

Dvouúrovňový model s devíti položkami měřícími individuální akademický optimismus s jeho třemi latentními konstrukty (vnímaná účinnost, důvěra $\mathrm{k}$ žákům a jejich rodičům a důraz na studijní výsledky) vykazoval dobrou shodu s daty (RMSEA $=0,058 ; \mathrm{CFI}=0,942 ; \mathrm{TLI}=0,924$; SRMR na úrovni učitele 0,06; SRMR na úrovni školy 0,11 ). To opět ukazuje, že fit na úrovni učitele je lepší než na úrovni školy. I zde jsou faktorové zátěže významné na obou úrovních $(p<0,001)$, přičemž faktorové zátěže na úrovni školy jsou silnější než na úrovni učitele, což ukazuje, že i zde působí akademický optimismus primárně na úrovni školy (viz tabulka 4). Residuální rozptyl latentní proměnné důvěra na úrovni školy (TR_SCH) byl zafixován na nulu (hodnota proměnné byla nízká a záporná). 
Tabulka 4

Dvouúrovňová konfirmační analýza, individuální akademický optimismus, Kalibro (faktorové zátěže na úrovni učitele a na úrovni školy)

\begin{tabular}{|c|c|c|c|c|c|c|}
\hline & \multicolumn{3}{|c|}{ úroveň učitele } & \multicolumn{3}{|c|}{ úroveň školy } \\
\hline & $\begin{array}{l}\text { vnímaná } \\
\text { účinnost } \\
\text { školy }\end{array}$ & $\begin{array}{l}\text { důvěra } \\
\text { k žákům } \\
\text { a rodičům }\end{array}$ & $\begin{array}{c}\text { důraz } \\
\text { na studijní } \\
\text { výsledky }\end{array}$ & $\begin{array}{c}\text { vnímaná } \\
\text { účinnost } \\
\text { školy }\end{array}$ & $\begin{array}{l}\text { důvěra } \\
\text { k žákům } \\
\text { a rodičům }\end{array}$ & $\begin{array}{c}\text { důraz } \\
\text { na studijní } \\
\text { výsledky }\end{array}$ \\
\hline SE1 & 0,689 & & & 0,987 & & \\
\hline SE2 & 0,764 & & & 0,844 & & \\
\hline SE3 & 0,619 & & & 0,857 & & \\
\hline TR1 & & 0,806 & & & 0,971 & \\
\hline TR2 & & 0,644 & & & 0,995 & \\
\hline TR3 & & 0,780 & & & 0,984 & \\
\hline AE1 & & & 0,485 & & & 0,632 \\
\hline AE2 & & & 0,733 & & & 0,974 \\
\hline AE3 & & & 0,731 & & & 0,995 \\
\hline & SE & $\mathrm{TR}$ & $\mathrm{AE}$ & SE_SCH & TR_SCH & AE_SCH \\
\hline $\mathrm{AO}$ & 0,807 & 0,848 & 0,672 & 0,775 & 1,000 & 0,998 \\
\hline
\end{tabular}

\subsection{Je pro zkoumání českých učitelů vhodnější individuální nebo kolektivní koncept?}

Na základě výsledků prezentovaných výše považujeme za vhodnější používat v českých výzkumech individuální koncept akademického optimismu. Oba výsledné modely vykazovaly dobrou shodu s daty. Abychom dosáhli této shody, museli jsme však kolektivní koncept ve srovnání s jeho originální podobou výrazně redukovat. Bližší pohled na položky, které byly v zájmu lepšího fitu z modelu odstraněny, vzbuzuje obavu, že původní koncept byl výrazně narušen. $Z$ modelu zmizely téměř všechny položky zaměřené na důvěru k žákům ve vztahu k jejich ochotě a schopnosti se učit, tedy není možno garantovat, že zůstal zachován původní obsah konstruktu. Rozhovory s učiteli nad lokalizovanými nástroji opět přinesly poznatek, že se učitelé zdráhají vypovídat o škole jako celku. Individuální koncept je navíc úspornější, a tedy vhodnější pro dotazování. 
5.4 Souvislost akademického optimismu a výsledků žáků v matematickém testu Posledním cílem naší analýzy na datech získaných v rámci projektu Kalibro bylo ověřit, zda akademický optimismus učitelů souvisí s výsledky žáků. Za tím účelem byl testován dvouúrovňový strukturní model, ve kterém byl vysvětlovanou proměnnou výsledek žáků 9. ročníku v matematickém testu. Na úrovni žáka bylo do modelu zahrnuto pohlaví a nejvyšší dosažené vzdělání rodičủ, které aproximovalo domácí zázemí žáků. Na úrovni školy byly vysvětlujícími proměnnými akademický optimismus zkonstruovaný prostřednictvím tří latentních proměnných, do kterých vstupovaly průměrné hodnoty jednotlivých položek za danou školu (_m), a agregované nejvyšší vzdělání rodičů, které charakterizovalo socioekonomické složení žáků školy.

\section{Úroveň žáka}
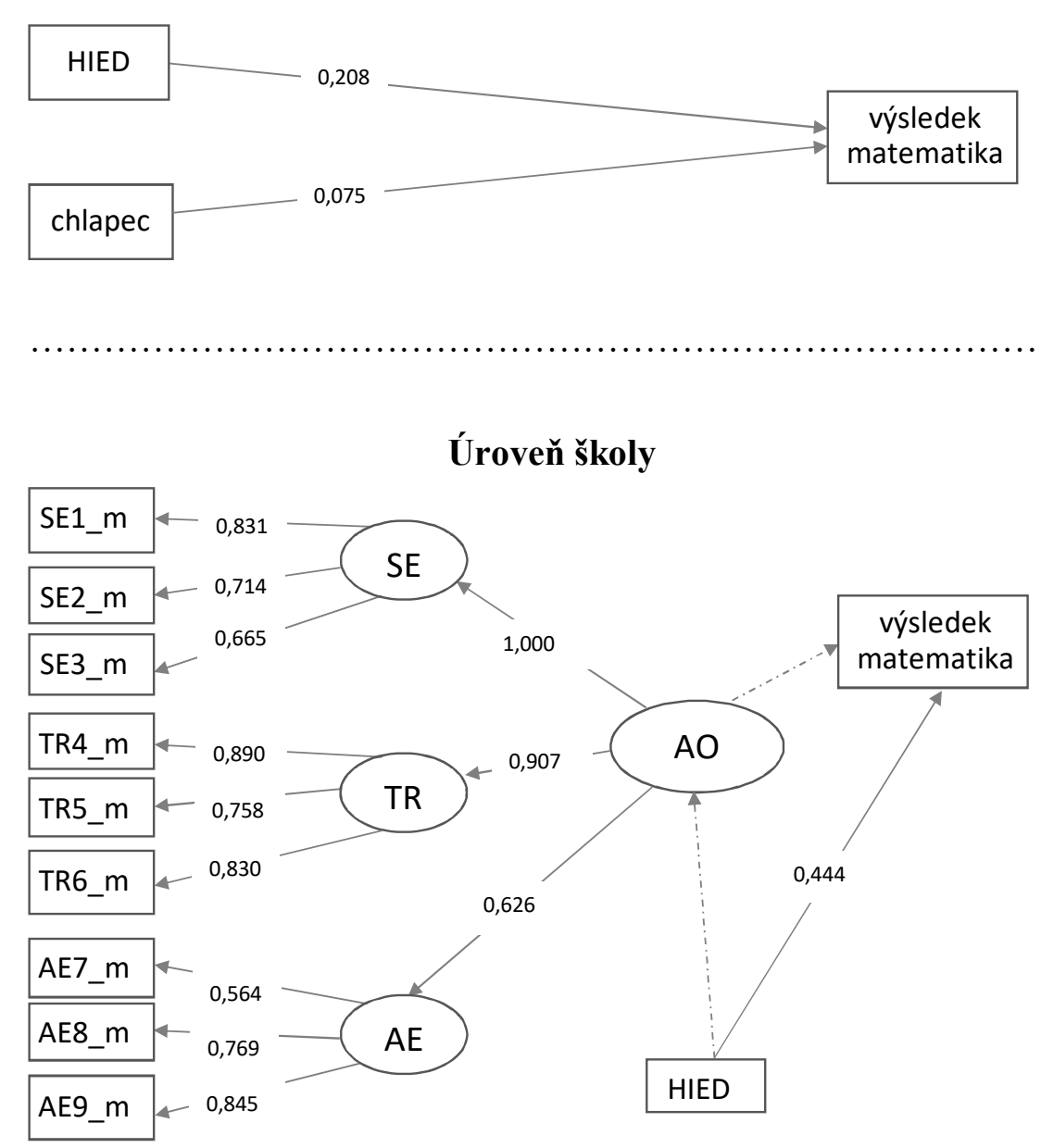

Obrázek 1. Dvouúrovňový strukturní model vysvětlující výsledek žáků 9. ročníku v matematickém testu. 
Model vykázal dobrou shodu s daty (RMSEA $=0,023 ;$ CFI $=0,9 ;$ TLI $=0,9$; SRMR na úrovni žáka 0,001; na úrovni školy 0,09). Na úrovni žáka se obě vysvětlující proměnné prokázaly jako statisticky významné: nejvyšší dosažené vzdělání $\mathrm{p}<0,001$, pohlaví (chlapec) $\mathrm{p}<0,05$. Na úrovni školy se prokázalo jako statisticky významné pouze socioekonomické složení žáků školy $(\mathrm{p}<0,001)$. Významná vazba nebyla shledána ani mezi akademickým optimismem a složením žáků školy, ani mezi akademickým optimismem a výsledkem v matematice. Výsledný model je znázorněn na obrázku 1.

\section{Diskuse a závěry}

Cílem analýz prezentovaných $\mathrm{v}$ této stati bylo upravit nástroje pro měření akademického optimismu pro české prostředí a ověřit, zda v českém prostředí fungují koncepty kolektivního a individuálního akademického optimismu. Cílem autorů bylo zároveň rozhodnout, který z obou konceptů je vhodnější pro použití v českém prostředí. Nástroje se podařilo lokalizovat a konfirmační faktorová analýza prokázala dobrou shodu dvouúrovňových modelů, které konstruovaly akademický optimismus ze tř́ latentních proměnných (vnímaná účinnost, důvěra a důraz na studijní výsledky) v př́ípadě obou konceptů. Aby se dosáhlo dobré shody, bylo však v případě kolektivního konceptu nutno z modelu odstranit osm položek. Jednalo se vesměs o položky, které se týkaly postojů učitelů $\mathrm{k}$ žákům a jejich předpokladů $\mathrm{k}$ učení. Odstraněním těchto položek ztratil nástroj svoji původní komplexitu.

Špatné fungování položek souvisejících s postoji učitelů k žákům a jejich učení může mít příčinu v obecně nízké důvěře českých učitelů ve své žáky, kterou prokázaly mezinárodní srovnávací výzkumy. Podíl učitelů primární školy, kteří ve výzkumu TIMSS a PIRLS 2001 souhlasili s tvrzením, že snaha jejich žáků ve škole dobře prospívat je velmi vysoká, respektive vysoká, byl $0,7 \%$, respektive $11,4 \%$, přičemž mezinárodní průměr byl $11,4 \%$, respektive 44,7\% (Mullis et al., 2012). Víra učitelů v žáky byla přitom identifikována jako klíčový faktor v př́ípadě výsledků žáků v sociálně a etnicky segregovaných školách (Dewulf, van Braak, \& Van Houtte, 2017). Je důležité prozkoumat detailněji zdroje nedůvěry českých učitelů v žáky a její povahu. Dosud přesně nevíme, zda se jedná o skutečnou nedůvěru nebo o postoj vyvěrající ze specifických epistemologických přesvědčení, která souvisejí také $\mathrm{s}$ nedůvěrou k systému. Čeští učitelé nedůvěřují systému a opakovaně upozorňují na nejistotu, kterou cítí ve vztahu k očekáváním společnosti od školy (Moree, 2013). 
Většina zahraničních studií využívá k hodnocení akademického optimismu zpravidla kolektivní koncept, který rovněž přizpůsobují lokálním potřebám (např. Boonen et al., 2014). Redukce však nebývá tak významná a jednostranná. $V$ českém prostředí navíc učitelé opakovaně projevovali neochotu se vyjadřovat $\mathrm{k}$ přesvědčení a práci svých kolegů a velmi dobře zde fungoval koncept individuální, který je navíc úspornější a pro respondenty tedy méně zatěžující. $\mathrm{Z}$ toho důvodu jsme se rozhodli používat $\mathrm{v}$ dalších výzkumech $\mathrm{v}$ českém prostředí individuální koncept akademického optimismu. Neochota českých učitelů vyjadřovat se $\mathrm{k}$ práci jejich kolegů může pramenit $\mathrm{z}$ toho, že spolu čeští učitelé velmi málo spolupracují. V šetření TALIS, které zkoumalo učitele 2. stupně povinného vzdělávání, například uvedlo $58 \%$ českých učitelů, že nikdy neučí ve spolupráci s jiným učitelem (Kašparová et al., 2013).

I když celková shoda modelu individuálního akademického optimismu s daty byla dobrá, faktorové zátěže v položkách hodnotících důraz na studijní výsledky žáků ukázaly, že model by bylo vhodné vylepšit ještě lepší lokalizací položek v této oblasti.

Dvouúrovňový strukturní model faktorů ovlivňujících výsledek žáků 9. ročníků v matematickém testu neprokázal souvislost mezi akademickým optimismem a výsledky žáků. Jako významné faktory související s výsledky se ukázaly na individuální úrovni rodinné zázemí a pohlaví (chlapec), na úrovni školy pak socioekonomické složení žáků školy. To odpovídá předchozím studiím, založeným na datech z výzkumu TIMSS. Ve výzkumu TIMSS 2011 byla ČR jednou z mála zemí, ve kterých neměly výsledky žáků souvislost se školním klimatem měřeným prostřednictvím ukazatele SEAS, který byl založen na konceptu akademického optimismu, ale byl koncipován odlišně (Martin et al., 2013). V analýze Strakové a Simonové (2015) byl akademický optimismus konceptualizován na základě dat z výzkumu TIMSS 2011 a prostřednictvím víceúrovňového modelování byla zkoumána jeho souvislost s výsledky žáků $\mathrm{v}$ matematickém testu a s některými nekognitivními výstupy vzdělávání. Analýza ukázala souvislost akademického optimismu s nekognitivními výstupy, ale nikoli s výsledky v matematickém testu.

Všechny uvedené výsledky je nicméně nutno považovat za předběžné. Martin a kol. (2013) pracovali s odlišným konceptem. Straková a Simonová (2015) konceptualizovaly akademický optimismus na základě dat dostupných ve výzkumu TIMSS 2011, ale nepoužily ověřených baterií k jeho měření. Ve výzkumu popsaném $v$ této stati jsme nepracovali s reprezentativním výběrem a zároveň jsme použili jako proměnnou charakterizující výsledek žáků výsledek 
testu Kalibro, který nenabízí psychometrické charakteristiky, na jejichž základě by bylo možno verifikovat jeho kvalitu. Koncept akademického optimismu považujeme za mimořádně nosný a popsaná studie prokázala, že se podařilo jej dobře adaptovat pro české prostředí. $V$ dalším výzkumu se zaměříme na to, abychom jeho souvislost s výsledky kognitivní i nekognitivní povahy ověřili na reprezentativním výběru a s pomocí ověřitelných nástrojů k měření výsledků.

\section{Literatura}

Amnesty International. (2015). Czech Republic: Must try harder - ethnic discrimination of Romani children in Czech schools. London: Amnesty International.

Anwar, M., \& Anis-ul-Haque, M. (2014). Teacher academic optimism: A preliminary study measuring the latent construct. FWU Journal of Social Sciences, 8(1), 10-16.

Bandura, A. (1986). Social foundations of thought and action. New York: Pretice-Hall.

Bandura, A. (1993). Perceived self-efficacy in cognitive development and functioning. Educational Psychologist, 28(2), 117-48.

Bandura, A. (1997). Self-efficacy: The exercise of control. New York: Freeman.

Beard, K. S., Hoy, W. K., \& Hoy, A. W. (2010). Academic optimism of individual teachers: Confirming a new construct. Teaching and Teacher Education, 26(5), 1136-1144.

Bevel, R., \& Mitchell, R. M. (2012). The effects of academic optimism on elementary reading achievement. Journal of Educational Administration, 50(6), 773-787.

Boonen, T., Pinxten, M., Van Damme, J., \& Onghena, P. (2014). Should schools be optimistic? An investigation of the association between academic optimism of schools and student achievement in primary education. Educational Research and Evaluation, 20(1), 3-24.

Byrne, B. M. (1998). Structural equation modeling with Lisrel, Prelis and Simplis: Basic concepts, applications and programming. Mahwah: Lawrence Erlbaum Associates.

Chang, I.-H. (2011). A study of the relationships between distributed leadership, teacher academic optimism and student achievement in Taiwanese elementary schools. School Leadership \& Management, 31(5), 491-515.

Coleman, J. S., Campbell, E. Q., Hobson, C. J., McPartland, J., Mood, A. M., Weinfeld, F. D., \& York, R. L. (1966). Equality of educational opportunity. Washington: US Government Printing Office.

Dewulf, L., van Braak, J., \& Van Houtte, M. (2017). The role of teacher trust in segregated elementary schools: A multilevel repeated measures examination. School Effectiveness and School Improvement, 28(2), 259-275.

Dvořák, D. (2015). Důraz školy na akademický úspěch: TIMSS 2011 jako sonda do reformy v České republice. Pedagogická orientace, 25(4), 583-604.

Eren, A. (2014). Uncovering the links between prospective teachers' personal responsibility, academic optimism, hope, and emotions about teaching: A mediation analysis. Social Psychology of Education: An International Journal, 17(1), 73-104.

Fahy, P. F., Wu, H. C., \& Hoy, W. K. (2010). Individual academic optimism of teachers: A new concept and its measure. In W. K. Hoy, \& M. DiPaola (Eds.), Analyzing school contexts: Influences of principals and teachers in the service of students (s. 209-227). Greenwich: Information Age. 
Hoy, W. (2012). School characteristics that make a difference for the achievement of all students: A 40-year odyssey. Journal of Educational Administration, 50(1), 76-97.

Hoy, W. K., Tarter, C. J., \& Woolfolk Hoy, A. (2006). Academic optimism of schools: A force for student achievement. American Educational Research Journal, 43(3), 425-446.

Hu, L. T., \& Bentler, P., M. (1998). Cutoff criteria for fit indexes in covariance structure analysis: Conventional criteria versus new alternatives. Structural Equation Modeling, 6(1), 1-55.

Kašparová, V., Boudová, S., Ševců, M., \& Soukup, P. (2014). Národní zpráva šetření TALIS 2013. Praha: Česká školní inspekce.

Kirby, M., \& DiPaola, M. F. (2011). Academic optimism and community engagement in urban schools. Journal of Educational Administration, 49(5), 542-562.

Akın Kösterelioğlu, M. (2017). The effect of teachers' shared leadership perception on academic optimism and organizational citizenship behaviour: A Turkish case. International Journal of Leadership in Education, 20(2), 246-258.

Martin, M. O., Foy, P., Mullis, I. V. S., \& O'Dwyer, L. M. (2013). Effective schools in reading, mathematics, and science at fourth grade. In M. O. Martin \& I. V. S. Mullis (Eds.), TIMSS and PIRLS 2011 (s. 109-178). Chestnut Hill: TIMSS \& PIRLS International Study Center, Boston College.

Mascall, B., Leithwood, K., Straus, T., \& Sacks, R. (2008). The relationship between distributed leadership and teachers' academic optimism. Journal of Educational Administration, 46(2), 214-228.

McGuigan, L., \& Hoy, W. K. (2006). Principal leadership: Creating a culture of academic optimism to improve achievement for all students. Leadership and Policy in Schools, 5(3), 203-229.

Moghari, E. H., Mas'oud, G. L., Bagherian, V., \& Afshari, J. (2011). Relationship between perceived teacher's academic optimism and English achievement: Role of self-efficacy. Procedia: Social \& Behavioral Sciences, 15, 2329-2333.

Moree, D. (2013). Teachers and school culture in the Czech Republic before and after 1989. Curriculum Journal, 24(4), 586-608.

Mullis, I. V. S., Martin, M. O., Foy, P., \& Arora, A. (2012). TIMSS 2011 international results in mathematics. Chestnut Hill: TIMSS \& PIRLS International Study Center, Boston College.

Ngidi, D. (2012). Academic optimism: an individual teacher belief. Educational Studies, 38(2), 139-150.

Nilsen, T., \& Gustafsson, J.-E. (2014). School emphasis on academic success: Exploring changes in science performance in Norway between 2007 and 2011 employing two-level SEM. Educational Research and Evaluation, 20(4), 308-327.

OECD (2014). TALIS 2013 results: an international perspective on teaching and learning. Paris: OECD Publishing.

Pajares, F. (2001). Toward a positive psychology of academic motivation. Journal of Educational Research, 95(1), 27-35.

Parsons, T., Bales, R. F., \& Shils, E. A. (1953). Working papers in the theory of action. New York: Free Press.

Reynolds, D., Sammons, P., De Fraine, B., Van Damme, J., Townsend, T., Teddie, C., \& Stringfield, S. (2015). Educational effectiveness research (EER): A state-of-the-art review. School Effectiveness and School Improvement, 25(2), 197-230.

Seligman, M. E. P. (1991). Learned optimism: How to change your mind and your life. New York: Knopf. 
Seligman, M. E. P. (1998). Positive social science. APA Monitor, 29(4), 5.

Sezgin, F., \& Erdogan, O. (2015). Academic optimism, hope and zest for work as predictors of teacher self-efficacy and perceived success. Kuram Ve Uygulamada Egitim Bilimleri, 15(1), 7-19.

Smetáčková, I., \& Vozková, A. (2016). Matematická self-efficacy a její měření v průběhu základní školy. E-Psychologie, 10(1), 18-33.

Smith, P., \& Hoy, W. K. (2007). Academic optimism and student achievement in urban elementary schools. Journal of Educational Administration, 45(5), 556-568.

Soukup, P. (2006). Proč užívat hierarchické lineární modely? Sociologický časopis/Czech Sociological Review, 42(5), 987-1012.

Straková, J., \& Simonová, J. (2016). Beliefs of Czech teachers as a prerequisite for effective teaching. Studia Paedagogica, 20(4), 53-70.

Straková, J., Spilková, V., Simonová, J., Friedleandaerová, H., \& Hanzák, T. (2013). Názory učitelů základních škol na potřebu změn ve školním vzdělávání. Orbis scholae, 7(1), 79-100.

Woolfolk Hoy, A., Hoy, W. K., \& Kurz, N. M. (2008). Teacher's academic optimism: The development and test of a new construct. Teaching and Teacher Education, 24(4), 821-835.

$\mathrm{Wu}, \mathrm{J}$. (2013). Academic optimism and collective responsibility: An organizational model of the dynamics of student achievement. Asia Pacific Education Review, 14(3), 419-433.

Wu, J., Hoy, W. K., \& Tarter, C. J. (2013). Enabling school structure, collective responsibility, and a culture of academic optimism. Journal of Educational Administration, 51(2), 176-193.

\section{Autoři}

Doc. RNDr. Jana Straková, Ph.D., Univerzita Karlova, Pedagogická fakulta, Ústav výzkumu a rozvoje vzdělávání, Myslíkova 7, 11000 Praha 1, e-mail: jana.strakova@pedf.cuni.cz

Mgr. Jaroslava Simonová, Ph.D., Univerzita Karlova, Pedagogická fakulta, Ústav výzkumu a rozvoje vzdělávání, Myslíkova 7, 11000 Praha 1, e-mail: jaroslava.simonova@pedf.cuni.cz

PhDr. David Greger, Ph.D., Univerzita Karlova, Pedagogická fakulta, Ústav výzkumu a rozvoje vzdělávání, Myslíkova 7, 11000 Praha 1, e-mail: david.greger@pedf.cuni.cz

\section{Verification of the concept of academic optimism on Czech lower secondary schools}

Abstract: Educational effectiveness research has proved the importance of teacher beliefs and attitudes for student learning. Beliefs strongly determine teachers' thoughts and actions and they ultimately influence student achievement, even though they might do so indirectly. A change of beliefs is a necessary prerequisite for changing practices and behaviours. Studies of beliefs and attitudes are based on various concepts. This study explores the concept of academic optimism and its functioning in the Czech education system. Academic optimism includes three important aspects 
of teachers' attitudes: self-efficacy, trust in students and their parents, and academic emphasis. It is operationalised as a collective characteristic of the school staff and as an individual characteristic of each teacher. This study explores the functioning of both the collective and individual measures and aims at selecting the more appropriate one for studying the environment of Czech schools. It also studies the relationship between academic optimism and student cognitive outcomes. The analyses are based on data from 39 basic schools, 325 lower secondary teachers, and 1316 grade 9 students collected in the Kalibro project in January 2016. Confirmatory factor analysis indicated the functioning of both the collective and individual concepts in the Czech environment; however, the individual one seems to be more appropriate for Czech schools. Two-level structural equation modelling based on this limited sample of schools and students has not confirmed a relationship between academic optimism and mathematical achievement. This relationship should be verified on a representative student sample using achievement tests that correspond better than the Kalibro test to the recent curricular norm.

Keywords: teacher attitudes, academic optimism, basic school, home background, student achievement

Havel, J., Janíková, M., Mužík, V., \& Mužíková, L. (2016). Analýza a perspektivy utváření pohybového a výživového režimu žákủ na prvním stupni základní školy. Brno: MU.

Monografie přináší výsledky dvouletého výzkumu, v němž kolektiv autorů analyzoval utváření pohybového a výživového režimu žáků na 1 . stupni 33 základních škol z celé České republiky. Kvantitativní část výzkumu byla orientována na zevrubnou deskripci obecných trendů ve zkoumaném procesu (a odhalení funkčních či nefunkčních prvků v něm), kvalitativní část byla zacílena na zjištění metod, forem a intervencí, které školy při utváření správného pohybového a výživového režimu žákủ uplatňují (včetně rozlišení specifik jednotlivých ročníků a škol). $V$ závěru publikace jsou nastíněny možné perspektivy implementace daného tématu do projektovaného i realizovaného kurikula, a to včetně př́pravného kurikula učitelů 1 . stupně základní školy. 
Tabulka P

Deskriptivní statistiky proměnných vstupujících do strukturního modelu

\begin{tabular}{lrrrrr}
\hline & $\mathrm{N}$ & Min & Max & průměr & SD \\
\hline chlapec & 1312 & 0,00 & 1,00 & 0,48 & 0,50 \\
výsledek & 1316 & 0,00 & 100,00 & 51,79 & 18,35 \\
hied & 1149 & 1,00 & 4,00 & 3,07 & 0,74 \\
SE1_m & 1316 & 3,20 & 4,67 & 3,90 & 0,32 \\
SE2_m & 1316 & 3,29 & 5,00 & 4,23 & 0,37 \\
SE3_m & 1316 & 3,57 & 5,17 & 4,53 & 0,35 \\
TR1_m & 1316 & 3,00 & 5,22 & 4,44 & 0,46 \\
TR2_m & 1316 & 2,71 & 4,79 & 4,07 & 0,42 \\
TR3_m & 1316 & 3,80 & 5,25 & 4,44 & 0,40 \\
AE1_m & 1316 & 3,83 & 5,83 & 4,92 & 0,39 \\
AE2_m & 1316 & 2,50 & 4,67 & 3,95 & 0,44 \\
Ae3_m & 1316 & 3,43 & 5,30 & 4,27 & 0,42 \\
HIED & 1316 & 2,33 & 3,71 & 3,06 & 0,26 \\
\hline
\end{tabular}

Vondráková, A., et al. (2016). Atlas vysokého školství v České republice 2001-2014. Olomouc: UP.

Atlas vysokého školství je společným dílem autorského kolektivu pracovníků Univerzity Palackého v Olomouci a Univerzity Karlovy a představuje kartografickou vizualizaci dat Individuálního projektu národního (IPN) KREDO Kvalita, relevance, efektivita, diverzifikace a otevřenost vysokého školství v ČR. Strategie vysokého školství do roku 2030. Atlas je rozdělen na jednotlivé kapitoly, které popisují infrastrukturu vysokých škol, demografické ukazatele a především statistiky týkající se absolventů a studentů českých vysokých škol ve sledovaném období. Př́ípadové studie jsou zaměřeny na ekonomické, chemické a ostatní technické obory, zdravotnické obory a na domácí univerzity autorského kolektivu, tj. Univerzitu Karlovu a Univerzitu Palackého v Olomouci. 